probably be more accurate, the simpler system appears to be more practical for everyday use. From the individual score the likelihood of finding serious disease could be assessed. Depending on resources and the number of investigations that the department is prepared to perform a cut off score could then be introduced. Patients referred by their general practitioner who fall below this level would be deferred, with the doctor retaining the option of seeking a consultant opinion.

An alternative way of restricting the numbers of investigations would be to exclude certain groups of patients in whom there is less likelihood of finding serious disease. This methodalthough more easily applicable-is not as effective as the scoring system. Whichever system is used, however, there will always be occasional patients with serious disease who do not meet the criteria for investigation. Fortunately, our results suggest that these are likely to be patients with peptic ulcer disease, as patients with malignant disease generally scored higher. Finally, if either system is introduced it must be appreciated that it is merely a guide to the likelihood of finding serious disease in an individual patient and as such may not be appropriate for some patients with obvious indications for endoscopy.

In conclusion we suggest that, subject to confirmation in further prospective studies, the introduction of a simple scoring system could greatly increase the cost effectiveness of endoscopy. It has greatest potential in assessing individual priority and for allowing optimum use to be made of limited resources. Although the system is particularly applicable to open access endoscopy, when it can be used to restrict the number of examinations performed, we are currently assessing its relevance for hospital based endoscopy.

\section{References}

${ }^{1}$ Fisher A, Surridge J, Vartan C, Loehry CA. Upper gastrointestinal endoscopy-a GP service. $\mathrm{Br}$ Med F 1977;ii:1199-201.

" Holdstock G, Wiseman $M$, Loehry C. Open access endoscopy service for general practitioners. Br Med f 1979; ; :457-9.

${ }^{3}$ Gear MWL, Barnes RJ. Endoscopic studies of dyspepsia in a general practice. Br Med f 1980;281:1136-7.

${ }^{4}$ Holdstock G, Bruce S. Endoscopy and gastric cancer. Gut 1981 ;22:673-6.

${ }^{5}$ Holdstock G, Colley S. Failure of increased use of endoscopy to influence complication rate of peptic ulcer disease. Br Med f 1983;287:393-4.

${ }^{6}$ Ashton EH, Healey MJR, Lipton S. The descriptive use of discriminant functioning in physical anthropology. Proc $R$ Soc Lond (Biol) 1967; 246 : $552-72$.

${ }^{7}$ Marton FI, Sox HS, Wasson J, Duisenberg CE. The clinical value of the upper gastrointestinal tract roentgenogram series. Arch Intern Med $1980 ; 140: 191-5$

${ }^{8}$ Mead GM, Morris A, Webster GK, Langman MJI. Use of barium meal examination in dyspeptic patients under $50 . \mathrm{Br} \mathrm{Med} \mathcal{F} 1977$; : 1460-1.

${ }^{9}$ Horrocks JC, DeDombal FT. Diagnosis of dyspepsia from data collected by a physician's assistant. $\mathrm{Br}$ Med f 1975; ;i :421-3.

10 Horrocks JC, DeDombal FT. Computer-aided diagnosis of dyspepsia. Dig Dis Sci 1975;2:397-406.

"Horrocks JC, Lambert DE, McAdam WAF, Morgan AG, Darnborough A, DeDombal FT. Transfer of computer-aided diagnosis of dyspepsia from one geographical area to another. Gut 1976;17:640-4.

${ }^{12}$ Horrocks JC, DeDombal FT. Clinical presentation of patients with dyspepsia. Gut 1978;19:19-26.

(Accepted 6 fuly 1983)

\title{
Effect of terbutaline sulphate in chronic "allergic" cough
}

\author{
R ELLUL-MICALLEF
}

\begin{abstract}
The effects of terbutaline sulphate were studied in 30 patients who presented with chronic cough at an allergy clinic. After a three week baseline period terbutaline and its placebo were given for two periods of three weeks each in a randomised, double blind, crossover manner. Patients kept a daily record of day and night cough scores and peak expiratory flow readings. Twenty one patients responded to terbutaline; placebo produced no significant effect. Both day and night cough scores $(p<0.001)$ and peak expiratory flow rates were significantly improved $(p<0.05)$ by the end of the first week of treatment with terbutaline. This improvement was achieved with only a fairly small change in airway calibre.
\end{abstract}

\section{Introduction}

Cough may be caused by a wide variety of conditions affecting different anatomical sites. ${ }^{1-3}$ Definitive treatment depends on

\footnotetext{
Department of Pharmacology, University of Kuwait, and Allergy Centre, Al-Sabah Hospital, Kuwait

R ELLUL-MICALLEF, MD, PHD, associate professor
}

Correspondence to: Dr R Ellul-Micallef, L'Arc-en-Ciel, San Anton Estate, Attard, Malta. establishing the underlying cause. Although cough, dyspnoea, and wheezing constitute the triad of classical symptoms of asthma, cough may precede the other symptoms or indeed be the sole manifestation of an allergic state, and this is often overlooked. In Kuwait chronic intractable cough, frequently non-productive, is common, particularly during the spring and summer. ${ }^{4}$ In the present study I assessed the effects of terbutaline sulphate in 30 patients who presented at an allergy outpatient clinic with chronic cough in the absence of dyspnoea.

\section{Patients and methods}

I studied 30 patients attending the allergy outpatient clinic over three years. They were prospectively selected if they presented with a chronic cough of at least three months' duration that was unaccompanied by dyspnoea or wheezing. None of the patients smoked or had any evidence of lung disease. The table shows clinical and physiological data on the patients studied. After a careful physical examination all patients underwent radiography of the chest and sinuses and electrocardiography. Bacteriological examination of the sputum was carried out whenever the cough was productive. In addition, blood specimens were examined for eosinophils, and prick skin tests with a wide variety of allergens were performed. No patient had been receiving antiasthma treatment before referral to the clinic. Most had previously received multiple courses of different antibiotics, antitussives, decongestants, and antihistaminics with no effect.

Before admission to the study reversibility of any airflow obstruction present was tested for with a dry wedge spirometer (Vitalograph), the forced expiratory volume in one second being measured before 
and after two puffs of a metered dose of terbutaline sulphate. Patients with normal spirometric values underwent histamine inhalation challenge with a standardised procedure ${ }^{5}$ on a separate occasion. After a three week baseline period patients were randomly assigned to receive $2.5 \mathrm{mg}$ terbutaline sulphate or a placebo tablet three times a day for three weeks; they then received the alternative preparation for three weeks. The study was carried out under double blind crossover conditions.

The patients were given diary cards to record the severity of their day and night cough. Day cough was scored as 0 if cough had been absent, $1-3$ if it was mild, 4-6 if moderate, $7-9$ if severe, and 10 if utterly exhausting. Similarly, night cough was scored as 0 if the patient ranged from $2 \%$ to $22 \%$ (mean $12.6(6) \%$ ). In all 24 patients in whom the initial forced expiratory volume in one second was greater than $85 \%$ of the predicted value a histamine inhalation challenge test resulted in a fall in forced expiratory volume in one second of at least $20 \%$, indicating the presence of bronchial hyperresponsiveness (table). In general, the lower the provocative histamine concentration that induced a $20 \%$ fall in forced expiratory volume in one second the greater the increase in forced expiratory volume in one second after salbutamol. When the forced expiratory volume in one second increased by more than $15 \%$ after salbutamol the provocative concentration that induced a $20 \%$ fall was always less than $0.5 \mathrm{~g} / 1$.

Analysis of the day and night weekly cough scores showed that

Data on patients studied, showing effect of terbutaline on forced expiratory volume in one second $\left(F E V_{1}\right)$ and provocative concentration of histamine $\left(P C_{20}\right)$ that induced a $20 \%$ fall in FEV

\begin{tabular}{|c|c|c|c|c|c|c|c|c|}
\hline \multirow{2}{*}{$\begin{array}{l}\text { Case } \\
\text { No }\end{array}$} & \multirow{2}{*}{ Sex } & \multirow{2}{*}{$\underset{\text { (years) }}{\text { Age }}$} & \multirow{2}{*}{$\begin{array}{l}\text { Duration of cough } \\
\text { (months) }\end{array}$} & \multicolumn{3}{|c|}{ Forced expiratory volume in one second (1) } & \multirow{2}{*}{$\begin{array}{l}\text { Blood eosinophils } \\
\left(\times 10^{6} / 1\right)\end{array}$} & \multirow{2}{*}{$\begin{array}{c}\mathrm{PC}_{20} \text { of histamine } \\
(\mathrm{g} / \mathrm{l})\end{array}$} \\
\hline & & & & Predicted & Initial & After terbutaline & & \\
\hline 1 & M & 16 & 9 & $4 \cdot 0$ & 3.85 & $4 \cdot 25$ & 470 & 2 \\
\hline 2 & $M$ & 18 & 5 & 3.80 & $4 \cdot 15$ & 4.50 & 355 & 2 \\
\hline 3 & $M$ & 22 & $\begin{array}{r}6 \\
48\end{array}$ & 3.75 & 3.55 & 4.05 & 563 & 0.5 \\
\hline 4 & $M$ & 43 & 48 & 3.60 & 3.80 & $4 \cdot 30$ & 610 & 0.5 \\
\hline 5 & $\underset{F}{M}$ & $\begin{array}{l}51 \\
23\end{array}$ & $\begin{array}{l}54 \\
10\end{array}$ & $3 \cdot 25$ & $2 \cdot 90$ & 3.55 & 484 & $0 \cdot 25$ \\
\hline 6 & $F$ & $\begin{array}{l}23 \\
30\end{array}$ & $\begin{array}{l}10 \\
18\end{array}$ & $\begin{array}{l}2 \cdot 80 \\
3.85\end{array}$ & $\begin{array}{r}2.60 \\
4.05\end{array}$ & $\begin{array}{r}2.75 \\
4.55\end{array}$ & $\begin{array}{l}720 \\
278\end{array}$ & 4 \\
\hline 8 & $\mathrm{~F}$ & $\begin{array}{l}30 \\
19\end{array}$ & $\begin{array}{r}10 \\
5\end{array}$ & 2.75 & $2 \cdot 65$ & $\begin{array}{l}4.33 \\
2.80\end{array}$ & $\begin{array}{l}278 \\
315\end{array}$ & 1 \\
\hline $\begin{array}{l}\circ \\
9\end{array}$ & $\mathrm{~F}$ & 35 & 24 & 3.0 & 3.30 & 3.85 & 525 & 0.25 \\
\hline 10 & $\mathrm{~F}$ & 25 & 18 & $3 \cdot 15$ & 2.90 & $3 \cdot 20$ & 491 & \\
\hline 11 & $M$ & 40 & 30 & $3 \cdot 20$ & $2 \cdot 80$ & 3.35 & 633 & 0.5 \\
\hline 12 & $\mathrm{M}$ & 37 & 36 & 3.45 & 3.40 & 3.65 & 580 & 2 \\
\hline 13 & $\mathrm{~F}$ & $\begin{array}{l}42 \\
55\end{array}$ & 60 & $2 \cdot 10$ & $\begin{array}{l}1.80 \\
2.45\end{array}$ & $2 \cdot 10$ & 473 & \\
\hline $\begin{array}{l}14 \\
15\end{array}$ & $\begin{array}{l}M \\
M\end{array}$ & $\begin{array}{l}55 \\
39\end{array}$ & $\begin{array}{l}96 \\
24\end{array}$ & $\begin{array}{l}3.05 \\
3.80\end{array}$ & $\begin{array}{l}2.45 \\
3.65\end{array}$ & $\begin{array}{l}2 \cdot 85 \\
4 \cdot 10\end{array}$ & $\begin{array}{l}655 \\
707\end{array}$ & 2 \\
\hline $\begin{array}{l}13 \\
16\end{array}$ & $\stackrel{M}{M}$ & $\begin{array}{l}39 \\
60\end{array}$ & $\begin{array}{l}24 \\
72\end{array}$ & 3.00 & $2 \cdot 30$ & $\begin{array}{l}4.10 \\
2.80\end{array}$ & 617 & 2 \\
\hline 17 & $\mathrm{M}$ & 32 & 48 & 3.65 & 3.45 & 3.75 & 188 & 8 \\
\hline 18 & $\mathrm{~F}$ & 63 & 96 & $2 \cdot 0$ & 1.55 & 1.90 & 463 & \\
\hline 19 & $\mathrm{~F}$ & 65 & 120 & $2 \cdot 25$ & 1.60 & 1.95 & 537 & \\
\hline 20 & $\mathrm{M}$ & 20 & 12 & $4 \cdot 15$ & 4.0 & $4 \cdot 25$ & 556 & 4 \\
\hline 21 & $M$ & 26 & 18 & 3.90 & $4 \cdot 25$ & $4 \cdot 40$ & 482 & 0.5 \\
\hline $\begin{array}{l}22 \\
23\end{array}$ & $\underset{F}{F}$ & $\begin{array}{l}24 \\
30\end{array}$ & $\begin{array}{r}6 \\
18\end{array}$ & $\begin{array}{r}2.80 \\
2.65\end{array}$ & $\begin{array}{l}3.05 \\
2.60\end{array}$ & $\begin{array}{l}3.50 \\
2.90\end{array}$ & $\begin{array}{l}806 \\
657\end{array}$ & 0.25 \\
\hline $\begin{array}{l}23 \\
24\end{array}$ & $\stackrel{F}{F}$ & $\begin{array}{l}30 \\
33\end{array}$ & 36 & $\begin{array}{l}2.03 \\
2.70\end{array}$ & $\begin{array}{l}2.00 \\
2.95\end{array}$ & $\begin{array}{l}2.90 \\
3.50\end{array}$ & $\begin{array}{l}057 \\
642\end{array}$ & 0.5 \\
\hline 25 & $M$ & 19 & 7 & $4 \cdot 40$ & 4.05 & $4 \cdot 15$ & 489 & 2 \\
\hline 26 & $\mathrm{M}$ & 41 & 54 & 3.30 & $3 \cdot 10$ & 3.25 & 305 & 4 \\
\hline 27 & $\mathrm{M}$ & 35 & 30 & 3.65 & 3.35 & 3.60 & 518 & 4 \\
\hline 28 & $\mathrm{~F}$ & 26 & 12 & $2 \cdot 80$ & 2.65 & $3 \cdot 10$ & 256 & 0.5 \\
\hline 29 & M & 43 & 66 & 3.40 & $2 \cdot 85$ & $3 \cdot 40$ & 472 & \\
\hline 30 & $\mathrm{~F}$ & 40 & 36 & 2.55 & $2 \cdot 70$ & 2.90 & 587 & 8 \\
\hline
\end{tabular}

had had a good night, 1-3 if he had slept well but had coughed slightly, 4-6 if he had been woken two or three times during the night, and 7-10 if he had had a bad night. Throughout the study each patient measured the peak expiratory flow rate with an Air Med minimeter immediately on waking and just before going to bed. The patients had been previously taught how to use the flow meter correctly and how to record their results. The best of three successive attempts was chosen and recorded. Statistical significance was tested in all instances with Student's $t$ test. $^{6}$

\section{Results}

Careful investigation of the patients failed to elicit specific causes for the cough other than "allergy." $X$ ray examination of the chest and sinuses yielded normal results in all cases. None of the patients had a history of heartburn or complained of a sour taste in their mouths, which would have indicated possible gastro-oesophageal reflux. Bacteriological examination of the sputum did not show any pathogens. As a chronic postnasal drip is a common cause of cough ${ }^{3}$ this was also carefully excluded clinically. Patients with rhinitis were not included in the study.

All the patients had a strong family history of atopy, and 19 of them suffered from other manifestations of allergy such as conjunctivitis or urticaria. Prick skin tests to the commonest allergens in Kuwait-namely, the pollens of Prosopis juliflora, Chenopodium album, and Cynodon dactylon ${ }^{4}$-yielded positive results in 27 patients. Blood eosinophilia was detected in 24 patients.

The initial forced expiratory volume in one second ranged between $71 \%$ and $110 \%$ of predicted values (mean (SD) $94.6(10.4) \%$ ). Although only six patients (cases 13,14,16,18,19, and 29) had an initial value less than $85 \%$ of the predicted value, the initial values in the patients overall were significantly lower than those predicted $(p<0.05)$. The presence of mild airflow limitation overall was further shown by the significant increase in forced expiratory volume in one second after two puffs of terbutaline $(p<0.001)$. This increase

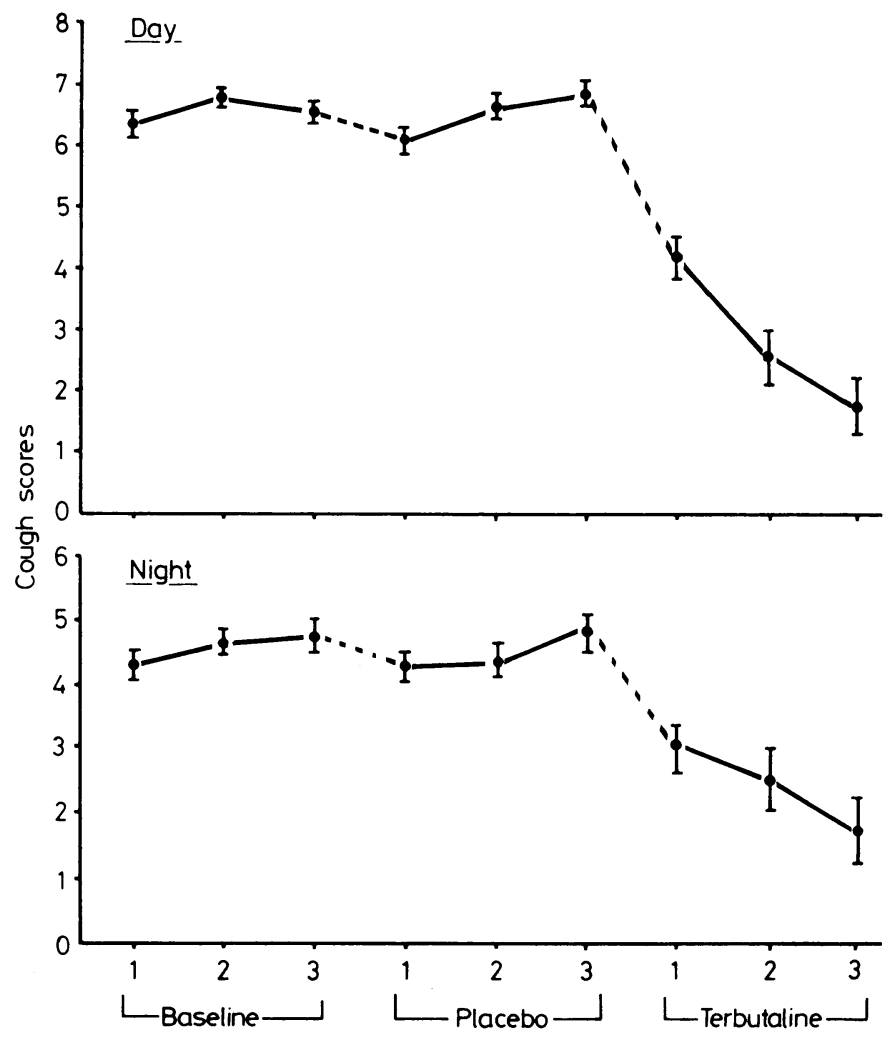

FIG 1-Day and night cough scores during three baseline weeks and three weeks of treatment with placebo and terbutaline. Values represent mean (SEM) scores for each respective week. 
placebo tablets did not result in any significant improvement $(p<0 \cdot 1$ for both day and night). In the group as a whole terbutaline sulphate produced a significant improvement $(\mathrm{p}<0.001)$ in both day and night weekly cough scores by the first week of treatment. This was sustained in the following two weeks (fig 1). Cough disappeared completely in 21 patients. In nine patients (cases 4, 5, 14, 16, 17, 18, 19, 26, and 28) the response was not considered to be clinically satisfactory. These patients received oral doses of prednisolone ranging from 15 to $30 \mathrm{mg}$ a day and tapered off over three weeks, which abolished their cough. Subsequent treatment with terbutaline maintained them cough free.

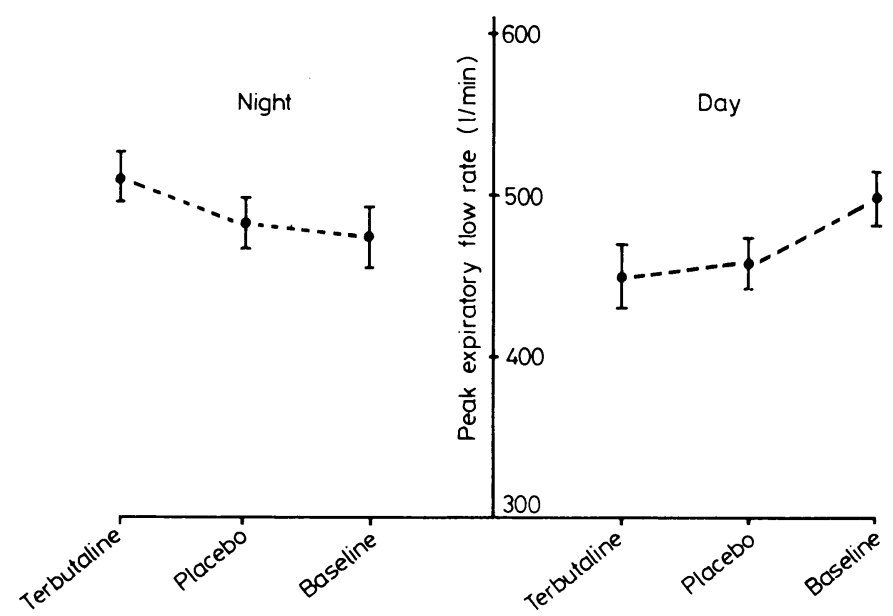

FIG 2-Day and night peak expiratory flow rates. Values represent mean (SEM) rates in each three week period of study.

In the group as a whole peak expiratory flow rates (fig 2) showed no significant change when the patients took placebo $(p<0 \cdot 1)$ but increased when they took terbutaline $(p<0.05)$.

\section{Discussion}

Colmes was the first to indicate that cough could be an independent symptom of allergy when he described a case due to "hypersensitiveness to Orris" ; three further cases were reported a year later. ${ }^{8}$ It has only recently been re-emphasised that cough may be a variant of asthma and precede the classical picture. ${ }^{9-12}$ Several reports have now been published showing the efficacy of bronchodilators in relieving this type of cough, but no placebo controlled, double blind trial has been carried out. The number of adults studied has been small, ${ }^{911}$ but one study of a fair number of children has been reported. ${ }^{12}$

Different types of cough occur in man, and little is known about their causative mechanisms ${ }^{2}$ : it appears that irritation of subepithelial receptors by various stimuli may result directly in cough via vagal pathways ${ }^{13}$ or may indirectly cause local narrowing of airways, which subsequently triggers off the cough reflex. ${ }^{14}$ In the present study bronchial hyperresponsiveness was present in all the patients who underwent histamine challenge. It is now firmly established that bronchodilators reduce bronchial responsiveness ${ }^{15-17}$ even when they produce no demonstrable bronchodilatation. ${ }^{17}{ }^{18}$ Although cholinergic reflexes play a part in bronchial hyperresponsiveness, ${ }^{19}$ a neurological mechanism does not account for all the features. ${ }^{20}$ Other factors, such as an intrinsic abnormality in bronchial smooth muscle, have been postulated. ${ }^{21}{ }^{22}$ Recent evidence, however, seems to indicate that bronchial hyperresponsiveness is an in vivo phenomenon resulting from factors other than hypersensitivity of bronchial smooth muscle to mediator release. ${ }^{23}$ Terbutaline may have produced its antitussive effect in the present patients by decreasing bronchial responsiveness. This may well have been the result of its non-specific effect of bronchodilatation. ${ }^{1823}$ In addition, it may have also acted on several mucosal structures, including epithelial tight junctions and irritant nerve endings, as well as on mast cells, thus reducing mediator release. ${ }^{2425}$

Terbutaline sulphate abolished the cough in most patients in this study within a week of the start of treatment. The appreciable decrease in cough scores was achieved with fairly small changes in airway calibre. A carry over effect was seen in several patients who changed from the active drug to placebo, but cough had returned in all cases by the fifth day of the first placebo week. This carry over effect was reflected by the overall lower day and night cough scores recorded in the first placebo week. The values shown in the figures represent recordings obtained before any prednisolone treatment. The nine patients in whom terbutaline failed to bring about a satisfactory response had all suffered from cough for at least two years. Corticosteroids probably brought about a remission of symptoms through their anti-inflammatory action, reducing mucosal permeability and thereby denying access to the irritant receptors in the epithelia and mast cells in the submucosa. Corticosteroids have been reported to alleviate severe cough in children with pertussis. ${ }^{26}$

All the patients in the group who knew how to use an inhaler properly were subsequently given aerosol treatment as this has been shown to afford the best protection in inhalation ${ }^{16}$ and exercise $^{27}$ challenge tests. A follow up study is under way to determine whether the classical picture of asthma will eventually develop in these patients who originally presented with cough as their sole complaint.

\section{References}

${ }^{1}$ Irwin RS, Rosen MJ. Cough: a comprehensive review. Arch Intern Med 1977;137:1186-91.

2 Widdicombe JG. Mechanism of cough and its regulation. Eur $\mathcal{F}$ Respir Dis 1980;61, suppl 110:11-20.

${ }^{3}$ Irwin RS, Carrao WM, Pratter MR. Chronic persistent cough in the adult: the spectrum and frequency of causes and successful outcome of specific therapy. Am Rev Respir Dis 1981;123:413-7.

${ }^{4}$ Ellul-Micallef R. Asthma in the desert. Thorax $1981 ; \mathbf{3 6}: 712$

${ }^{5}$ Chai J, Farr RS, Frochlich LA, et al. Standardization of bronchial inhalation challenge procedures. F Allergy Clin Immunol 1975;56: 323-7.

' Snedecor GW, Cochran WG. Statistical methods. Ames, Iowa: Iowa State University Press, 1971.

' Colmes A. Cough due to hypersensitiveness to Orris. $N$ Engl $\mathcal{F} \mathrm{Med}$ $1929 ; 200: 389-90$.

^ Colmes A, Rackemann FM. Cough as a manifestation of human hypersensitiveness. FAMA 1930;95:192-4.

9 Glauser FL. Variant asthma. Ann Allergy 1972;30:457-9.

10 McFadden ER Jr. Exertional dyspnoea and cough as preludes to acute attacks of bronchial asthma. N Engl f Med 1975;292:555-9.

11 Carrao WM, Braman SS, Irwin RS. Chronic cough as the sole presenting manifestation of bronchial asthma. N Engl f Med 1979;300:633-7.

12 Hannaway PJ, Hopper DK. Cough variant asthma in children. $\mathcal{F} A M A$ $1982 ; 247: 206-8$.

${ }^{13}$ Simonsson BG, Jacobs FM, Nadel JA. Role of autonomic nervous system and the cough reflex in the increased responsiveness of airways in patients with obstructive airway disease. $\mathcal{F}$ Clin Invest $1967 ; \mathbf{4 6}: 1812-8$.

1 Sevelius H, Colmore JP. Antitussive effects of ethyl dibunate in patients with chronic cough. Clin Pharmacol Ther 1967;8:381-4.

15 Booj-Noord H, Quanjier PH, deVries K. Protective effect of Berotec in provocation tests using inhalation of specific allergens and histamine. Int $\mathcal{F}$ Clin Pharmacol 1972;4:69-72.

${ }^{16}$ Cockcroft DW, Killian DN, Mellon JJA, Hargreave FE. Protective effect of drugs on histamine-induced asthma. Thorax 1977;32:429-37.

17 Salome CM, Schoeffel RE, Woolcock AJ. Effect of aerosol and oral fenoterol on histamine and methacholine challenge in asthmatics. Thorax $1981 ; \mathbf{3 6}: 580-4$.

18 Tattersfield AE. Measurement of bronchial reactivity: a question of interpretation. Thorax $1981 ; 36: 561-5$.

19 Empey DW, Laitinen LA, Jacobs L, Gold WM, Nadel JA. Mechanisms of bronchial hyper-reactivity in normal subjects after upper respiratory tract infection. Am Rev Respir Dis 1976;113:131-9.

20 Holtzman MJ, Sheller JR, Dimeo M, Nadel JA, Boushey HA. Effects of ganglionic blockade on bronchial reactivity in atopic subjects. Am Rev Respir Dis 1980;122:17-25.

"1 Antonissen LA, Mitchell RW, Kroeger EA, Kepron W, Tse KS, Stephens NL. Mechanical alteration of airway smooth muscle in a canine asthmatic model. F Appl Physiol 1979;46:681-7. 
${ }^{22}$ Ryan G, Latimer KM, Dolovich J, Hargreave FE. Bronchial responsiveness to histamine: relationship to diurnal variation of peak flow rate, improvement after bronchodilator, and airway calibre. Thorax 1982; 37:423-9.

${ }^{23}$ Dahlén S-E, Hansson G, Hedqvist P, Björck T, Granstörm E, Dhalén B. Allergen challenge of lung tissue from asthmatics elicits bronchial contraction that correlates with the release of leukotrienes $C_{k}, D_{4}$ and $\mathrm{E}_{4}$. Proc Natl Acad Sci USA 1983;80:1712-6.

${ }^{24}$ Benson MK. Bronchial hyperreactivity. Br $\mathcal{F}$ Dis Chest 1975;69:227-39.

${ }^{25}$ Orange RP, Austen WG, Austen KF. Immunological release of histamine and slow-reacting substance of anaphylaxis from human lung. $\mathcal{F} \operatorname{Exp}$ Med 1971;134:136-48s.

${ }^{26}$ Zoumboulakis D, Anagnostakis D, Albanis V, Matsaniotis N. Steroids in treatment of pertussis. A controlled clinical trial. Arch Dis Child 1973;48:51-4.

27 Anderson SD, Seale JP, Rozea P, Bandler L, Theobald G, Lindsay DA. Inhaled and oral salbutamol in exercise-induced asthma. $A m \operatorname{Rev}$ Respir Dis 1976;114:493-500.

(Accepted 12 fuly 1983)

\title{
Fetal distress and the condition of newborn infants
}

\author{
G S SYKES, PAULA M MOLLOY, P JOHNSON, G M STIRRAT, A C TURNBULL
}

\begin{abstract}
In a prospective audit of the obstetric management of 1210 consecutive deliveries the association was investigated between the need for operative delivery for fetal distress during labour and the condition of the newborn infant. Operative delivery was performed for only $11.5 \%$ of the newborn infants with severe acidosis at birth (umbilical artery pH $<7 \cdot 12$, base deficit $>12 \mathrm{mmol}$ $(\mathrm{mEq}) / \mathbf{1}), \mathbf{2 4} \cdot \mathbf{1} \%$ of those with an Apgar score $<7$ at one minute, and $15.8 \%$ of those with both severe acidosis and a one minute Apgar score $<7$. Most of the infants delivered operatively were in a vigorous condition at birth and did not have severe acidosis. Fetal blood sampling was done in $4.0 \%$ of labours. As none of the fetal blood values were less than $7 \cdot 20$ and only three of the infants sampled in utero suffered severe acidosis at birth, fetal blood sampling would have had to be performed much more often to provide a useful guide to metabolic state at birth. While the large majority of "at risk" fetuses had continuous fetal heart rate monitoring in labour, this had not been provided in $48.7 \%$ of the labours of infants with severe acidosis, $38.7 \%$ of infants with a one minute Apgar score $<7$, and $47.4 \%$ of infants with both severe acidosis and a one minute Apgar score $<7$. Continuous fetal heart rate monitoring was associated with a much higher incidence of operative delivery for fetal distress than was intermittent fetal heart rate auscultation.
\end{abstract}

These results suggest an urgent need to review present methods for assessing the intrapartum condition of the fetus, making the diagnosis of fetal distress, and assessing the condition of the infant at birth.

Nuffield Department of Obstetrics and Gynaecology, John Radcliffe Hospital, Oxford

G S SYKES, MRCOG, research fellow

PAULA M MOLLOY, SRN, SCM, research midwifery sister

P JOHNSON, MB, BS, honorary consultant in clinical physiology

G M STIRRAT, MD, FRCOG, clinical reader in obstetrics and gynaecology

A C TURNBULL, MD, FRCOG, Nuffield professor of obstetrics and gynaecology

Correspondence to: Dr P Johnson.

\section{Introduction}

Fetal distress is a relatively common indication for operative delivery. The diagnosis is usually based on characteristic changes in fetal heart rate assessed by auscultation or electronic recording with, in some cases, low $\mathrm{pH}$ in a fetal blood sample. ${ }^{1-3}$ At this hospital continuous monitoring of fetal heart rate is done largely in only "at risk" labours, as the results of randomised controlled trials of fetal monitoring ${ }^{4-8}$ are not considered to justify a policy of extending continuous fetal heart rate monitoring to all. Analysis of umbilical cord blood samples of at risk newborn infants showed that their acid base state at delivery was not related to the clinical diagnosis of fetal distress, raising doubts about the effectiveness of intrapartum fetal surveillance. Since severe fetal metabolic acidosis due to hypoxia is thought to be important in asphyxial damage in the newborn, ${ }^{3} 9$ and since it was not known how closely clinical diagnosis of fetal distress was associated with severe acidosis at birth or the clinical condition of the newborn infant, a prospective audit of these factors was conducted in 1000 consecutive deliveries managed by routine methods.

\section{Methods}

The clinical condition of newborn infants was assessed by Apgar score and their biochemical condition by measuring umbilical artery blood values. Umbilical cords were double clamped immediately after delivery, samples collected anaerobically into preheparinised polyethylene syringes, and were analysed as soon as possible using an ABL-3 Acid-Base Laboratory (Radiometer, Copenhagen). If immediate analysis was not possible the capped syringes were immersed in crushed ice and stored in the refrigerator. In this study umbilical artery $\mathrm{pH}$ and base deficit were investigated, as they provide a reliable indication of the degree of fetal tissue metabolism at delivery. "Severe acidosis" was defined as being present when both umbilical artery $\mathrm{pH}$ and base excess measurements were one standard deviation below the mean of the population studied.

Patient management was not modified in any way during the audit period. All information was obtained by scrutinising the case notes and stored fetal heart rate recordings. When the primary indication for operative delivery was fetal distress a newborn infant was classified as having had an "operative delivery for fetal distress." The obstetrician's diagnosis of fetal distress was usually based on concern about the fetal heart rate, occasionally on fetal blood $\mathrm{pH}$, and sometimes on other observations. The usual indications for continuous fetal heart rate monitoring were poor obstetric history, hypertension, pre-eclampsia, diabetes, antepartum haemorrhage, intrauterine growth retardation, prematurity, malpresentation, epidural anaesthesia, oxytocin infusion, meconium stained liquor, an auscultated fetal heart rate $<120$ beats/min, $>160$ beats $/ \mathrm{min}$, or with excessive irregularity, "trial of scar," and "trial of labour"; however, the decision about the method of fetal heart rate monitoring was made 